\title{
THE USE OF HEROISM IN THE ZIMBABWE AFRICAN NATIONAL UNION-PATRIOTIC FRONT (ZANU- PF) INTRA-PARTY FACTIONAL DYNAMICS
}

\section{Tyanai Masiya \\ School of Public Management, University of Pretoria and Godfrey Maringira Department of Anthropology and Sociology, University of The Western Cape, Bellville}

\section{Abstract}

Much of what we know about Zimbabwe's liberation war heroes and heroines is associated with the Zimbabwe African National UnionPatriotic Front (ZANU-PF)'s recognition of individuals who defended its hold on power. However, of late, an upsurge in factionalism in the party has resulted in increasing reference to heroism as a means to exert factional dominance. An understanding of how this has been done can be used to explain ZANU-PF factional dynamics. Current studies call for the study of factionalism to focus on intra-party group dynamics instead of the traditional organisation forms of factions. It is in this context that this study argues that survival or fall of factions within (ZANUPF) is framed around issues of heroism that is around one's perceived contribution or non-contribution to the liberation struggle. This article demonstrates this growing phenomenon in ZANU-PF by analysing five wellknown ZANU-PF veteran leaders whose status has been reshaped by new political moments as factionalism intensified. In light of rising factionalism, we argue that, war hero/heroine status in ZANU-PF is not permanent, but is highly shaped by obtaining factional political moments. 


\section{Introduction}

In post-colonial Africa, factionalism is still a relatively understudied phenomenon, although becoming more common. In the Zimbabwean context, factionalism relates to a gruesome struggle for power to control party positions and the policy direction of the party by sub groups of individuals within a political party. Understanding intra-party factional dynamics in ZANU-PF is in line with current calls to study factional dynamics instead of organisational forms of factions "since what needs studying if we are to explain outcomes is group dynamics - interactions between factions, host parties and voters - in other words, factionalism and its transformation" (Boucek 2009: 14). In simple terms, what is important about factions is not their structural properties but their activity and its consequences. Factionalism can be pursued in different ways at different times and under different conditions. In ZANU-PF factional fights, heroism, based on one's alleged contribution to the liberation struggle is taking central stage. As can be exemplified by the events around the party's 2014 congress, heroes/heroines can be 'made' or stripped of status within the factional fights. Traditionally, ZANU-PF's image as a party is built around its contribution to the liberation struggle and its invincibility over whites and the Western world. From a ZANU-PF perspective, heroes and heroines are seen as individuals who defended their country by standing with and defending the party. Werbner (1998: 99) states that, "Zimbabwe provides the example of a post-colonial nation-building regime which tries to turn the trace of the past into prestige and legitimacy for itself and tribute for others". However, limited attention has been paid to how the liberation hero status is conveniently used in the party's rising factional fights.

Although the definition of hero and heroine is a slippery one and has been challenged by different scholars (Danderker et al 2006; Alexander and Mcgregor 2004) this article contends that as a result of intensifying factionalism in ZANU-PF, one now needs to be intimately connected to a dominant ZANU-PF faction in order to be recognised as a hero in addition to having had a presence in the bush war. While war hero status is often announced by ZANU-PF when an individual dies, this study argues that the status itself is not limited to the dead but also to the living and when they die by being buried at state shrines popularly known as heroes acres at national, provincial and district levels.

A number of strategies are used within ZANU-PF in the process of discrediting or praising individuals during factional battles. These in- 
clude using perceived leaders who served in the war front as witnesses; using state media that usually supports the party and its leadership, particularly president Mugabe, to further expose the person as a charlatan or praising him/her as a hero/heroine. The party president praises or castigates concerned individual in his speeches. Of late, however, as Mugabe is aging, his wife, Grace Mugabe has also entered the arena of shaping factional battles in ZANU-PF. In this regard, we argue that the party's reference to this status cannot be relied upon as a measure of one's past participation in the liberation struggle but as a measure of an individual's circumstances within factions. Rather this article argues that status is intricately related to the prevailing political relations of the individual within ZANU-PF and in particular with President Robert Mugabe.

The article reveals how the hero status of an individual is constructed within the ZANU-PF party through the narrative of the liberation war, but more importantly explores the ways in which such status mutates over time. This is done by tracing five well-known ZANU-PF figures, namely former Vice President, Joice Mujuru; former Minister of Presidential Affairs, Didymus Mutasa; former Minister of State Security, Nicholas Goche; former War Veterans Association Chairman, Jabulani Sibanda, and former Information and Publicity Secretary in ZANU-PF, Rugare Gumbo. Our choice to focus on them stems from the very fact that these were once celebrated in as heroes in the party. They were later criticised as villains and 'sell-outs' due to factional differences. Furthermore, the deliberate labelling of these individuals as villains of the struggle and subsequent expulsion from the party, regardless of having spent decades being regarded as heroes marks the most extreme form of action that the party has taken against any faction since the turn of the century as a result of fierce intra-party factionalism.

\section{Hero status in ZANU PF: A background}

Zimbabwe became independent in 1980 after a protracted war between armed guerrilla fighters and white minority Rhodesian forces. Combatants of every rank from the Zimbabwe National Liberation Army (ZANLA) and the Zimbabwe People's Liberation Army (ZIPRA) were recognised at independence for their contribution to the struggle for liberation with those who held higher ranks in the guerrilla military being more revered (see Chung 2006). Also recognised were liberation war leaders who served in various civilian ranks particularly in developing the support network, raising resources, recruiting fighters and engaging 
in negotiations with foes and friends (Chung 2006).

However, many ZAPU and ZIPRA linked would-be war heroes were marginalised as a result of the outbreak of a ZAPU linked insurgency in the early 1980s and were accused of being 'sell-outs' (Alexander 1998). This marked the era in post liberation war Zimbabwe when any party, organisation or individual who opposed ZANU-PF monopoly would be stripped of his/her liberation war hero status. Many ZIPRA cadres were labelled as 'dissidents', and President Robert Mugabe responded by deploying the North Korean trained $5^{\text {th }}$ Brigade of the Zimbabwean army to unleash violence against 'dissidents' and civilians alike (Ndlovu-Gatsheni 2009: 152). During this period ZIPRA veteran leaders such as Lookout Masuku and Dumiso Dabengwa were arrested and detained without trial (Alexander 1998). Joshua Nkomo, ZAPU's leader, went into exile. Other war heroes who fought on the wrong side of ZANU-PF or belonged to smaller parties also lost the hero label from a ZANU-PF perspective (Mhanda 2011). As such, would be heroes such as Ndabaningi Sithole (ZANU's first president), James Chikerema and Wilfred Mhanda among others were denied the accolade. Forming their own political parties in the 1990s, Edgar Tekere, Margret Dongo and Enock Dumbutshena also faced various forms of vilification (Chikuhwa 2004).

Nonetheless, those who later joined ZANU-PF had their hero status restored. Prime among these was Joshua Nkomo, later described as 'father Zimbabwe' despite wearing the 'sell-out and dissident' tag in the 1980s (Ndlovu-Gatsheni 2009). This information corroborates the view that ZANU-PF and President Robert Mugabe's view of heroes has always been driven by the zeal to fulfil their own political agendas and to remain in power. They have never been tolerant of other liberation war figures who did not belong to ZANU-PF. However, vicious intraparty factional fights within ZANU-PF have grown in the last decade and have seen a similar strategy being applied to members or group of members who have fallen out of favour with the establishment within ZANU-PF.

Hence this study discusses heroism within the context of this rising intra-party factionalism. Prior to discussing the use of hero status in ZANU-PF factionalism it is paramount to first outline the way these heroes have been identified in general in the past. As previously stated it is important to note that heroism is notable among previous participants in the liberation struggle whether dead or alive. However, upon death, the ZANU-PF politburo decides where each particular hero would be buried. Three options exist namely, district heroes' acre, provincial 
heroes' acre and the national heroes' acre. In theory, Zimbabwean statutes (War Veteran Act of 1992) delimit veterans of the struggle to cover those who, "participated, consistently and persistently, in the liberation struggle which occurred in Zimbabwe and in neighbouring countries between the 1st January, 1962, and the 29th February, 1980, in connection with the bringing about of Zimbabwe's independence on the 18th April, 1980".

The Act however sparked controversy, even among liberation fighters, as many felt excluded. For example, the use of 'consistently' and 'persistently' in the Act above indicates that, even those who fled during the liberation war or were wounded and could not continue fighting in the war, were not considered war veterans (see Goredema and Chigora 2009)

As a result of the contentions about who is a liberation struggle hero, ZANU-PF and President Mugabe have constructed their own understanding of the term. Goredema and Chigora (2009) point out that President Mugabe and his party politburo reserve the right to determine who is a veteran hero or heroine of the struggle and this has sparked a lot of discontentment amongst other parties, such as civil society at large as the majority of the stakeholders are not clear on the criteria used to classify them. It seems to be more of a privilege extended by Mugabe and ZANU-PF. According to Baines (2009: 331) "memorials serve as significant markers of postcolonial society's (re)construction of its past". But in the Zimbabwean context, the recognition of the heroes is more of the present than past historical participation in the liberation struggle. The past memories of war are renewed and reconstructed in the present (Baines 2009).

It is in this context that we contend that the rise in factionalism has seen ZANU-PF intra-party groups extending their recognition of war heroism to focus on eliminating fellow members who have lost favour in the eyes of President Mugabe and the party. It has been easier to use this strategy because ZANU-PF's post-colonial nationbuilding mantra has always turned the traces of the past Chimurenga (liberation wars) into prestige and legitimacy.

\section{Factionalism: A theoretical perspective}

Faction is used in this study to refer to "a structured group within a political party (and in this case, ZANU-PF) which seeks, at a minimum, to control authoritative decision-making positions of the party" (Zuckerman 1975: 20). According to Zariski (1960: 33), factionalism should be 
viewed as:

Any intra-party combination, clique, or grouping whose members share a sense of common identity and common purpose and are organised to at collectively - as a distinct bloc within the party - to achieve their goals. These goals may include any, several, or all of the following; patronage (control of party and government office by members of the faction), the fulfilment of local, regional, or group interests, influence on party strategy, influence on party and governmental policy, and the promotion of a discrete set of values to which members of the faction subscribe.

This definition is corroborated by Belloni and Beller (1978: 419) who also point out that factionalism refers to sub units existing within political parties that engage in collective action to pursue their objective or to secure power advantages within the party. In that regard they are organisational units of competition within political parties. These competing groups seek to have a dominant role in influencing the direction of the party. In the context of ZANU-PF, factions also tend to position themselves for a potential party leadership takeover. Political parties are characterised by competition, divided opinions and dissent which creates internal fissures that result in factions.

Boucek (2009) identifies three faces of factionalism, namely cooperative, degenerative or competitive. Where factionalism is cooperative, it has the potential to build consensus in a given political party. Cooperative factionalism may emerge from transitions to democracy, party mergers and party splits. It provides for the articulation of policy opinions and preferences of separate societal groups and different communities by different factions in a given political faction. In the case of ZANU-PF, cooperative factionalism was popularised by the inclusive government at independence in 1980 and in particular following the merger of ZANU-PF and PF ZAPU in 1987, thereby providing a mechanism for internal conflict resolution through factional power sharing. Since the merger, the party always provided for the interest of the original parties in its leadership hierarchy. For example, the chairperson of the party and one of the party's vice presidents would always come from members who initially belonged to PF ZAPU. This strengthened the party and fostered unity among its members. Thus cooperative factionalism in this case provided a logical and orderly means of leadership selection and rotation. It also had the effect of skewing political competition and one party dominance on the Zimbabwean political landscape in favour of ZANU-PF for over a decade. 
Degenerative factionalism occurs when a party fails to put a check on factionalism to the extent that the party faces collective action challenges (Boucek 2009). This often occurs if factions are given official status as this may lead to excessive fragmentation that may result from focussing attention away from the party towards interests of the factions or their leaders (Cox et al 2000). In certain circumstances this may lead to self-serving interests, corruption and party instability resulting from minority factions constantly shifting and aligning themselves with different factions (Bettcher 2005). Giving an example of Italy's former Christian Democrats (DC), which in 1964 decided to adopt a system guaranteeing leadership positions for faction in the party and in government, Boucek (2009) contends that this created incentives for fragmentation as new factions formed and existing factions split. Due to the multiplicity of factions, inter-factional alliances were unstable as leaders of minority factions constantly repositioned themselves to put their faction inside the winning coalition thereby increasing personal power and position within the DC and payoffs in the next government. It therefore promotes self-serving behaviour by faction leaders. In the end "factional politics dictated the size and composition of Italian cabinets to such an extent that new appointments and additional government portfolios were often created simply to satisfy the particular interests and demands of DC faction leaders even if these posts carried no particular responsibilities" (Boucek 2009: 24).

The third face of factionalism is competitive factionalism. In competitive factionalism, "divergent factional preferences and polarised party opinion create splitting pressures and loosen intra-party ties as factions become opposed rather than simply splitting" (Boucek 2009: 19). Often this occurs when factions disagree on deep-seated issues that are difficult to integrate within party ideology. One key characteristic of this type of factionalism is that it can be episodic but very destabilising for any political party. Under competitive factionalism, sometimes issues causing factions to arise may disappear but reappear in the future if similar circumstances arise. Thus intra-party competitive factionalism may produce outcomes that threaten party unity, especially where intraparty electoral competition exists. However, party organisational arrangements influence how the management of factions is done. Competitive factionalism has been rising in ZANU-PF and accounts for the events around the party's 2014 congress.

Competitive factionalism in ZANU-PF has led to deep political differences with some faction leaders (including President Mugabe) appearing to pursue a far leftist ideology while others have preferred more 
moderate ideologies. Another factor that seems to have caused a recurrence of factionalism in the last few years has been President Robert Mugabe's old age and the tussling of factions with a view to taking over leadership. However, any faction that aligns itself with President Mugabe has tended to eventually dominate albeit temporarily. This is because of Mugabe's autocratic leadership style as well as the party's organisational arrangements. As a result, towards any party congress party leaders from provinces jostle to endorse President Mugabe and give him the leeway to nominate his deputies. Any factions that lose at congress have tended to receive punishments of various magnitudes. For example, when Vice President Emmerson Munangagwa's faction lost in 2004, various accusations were levelled against them leading to the suspension of many of the faction's leaders who were in the top leadership. Prime among the accusations was the alleged Tsholotsho Declaration, a meeting they held, which was later viewed as an attempted coup on Mugabe. The latest faction to fall out of favour with Mugabe and subsequently the party was that led by former Vice President, Joice Mujuru, which is the subject of this discussion.

\section{The 2014 Congress and changing hero status}

As highlighted earlier, in the Zimbabwean context, heroes are those individuals who ZANU-PF narrates as having played key roles in the liberation struggle. However, this article specifically discusses how liberation struggle heroism is framed around party members in ZANUPF's factional struggles as a means of either propping up their image or portraying them as villains with reference to the 2014 congress events that stripped five leaders of their war hero and heroine status. These leaders are, namely Joice Mujuru, Didymus Mutasa, Rugare Gumbo, Nicholas Goche and Jabulani Sibanda. These belonged to the Mujuru faction whose star had been phenomenally rising till a few months towards the ZANU-PF 2014 Congress, which was challenged by the Emmerson Mnangagwa faction that had the first lady Grace Mugabe as the figurehead (Makinwa 2015). The Congress and its aftermath saw their expulsion as well as lesser figures such as members of parliament, Politburo figures, Central committee members, provincial and district leaders.

Then Vice President, Joice 'Teurai Ropa' Mujuru (originally Runaida Mugari) once acknowledged within ZANU-PF and by Mugabe 
himself as his heir apparent (Mail and Guardian, 5 December 2004), was one of the top party leaders to fall by the wayside. She was presented as a villain rather than a heroine despite past praises.

When she was still presented as a heroine, as popularised by ZANU-PF, it is recorded that she left school, after two years of secondary education, to join the liberation struggle in 1973. It was also reported that she downed a British helicopter with a machine gun on 17 February 1974 after refusing to flee with fellow fighters as the enemy attacked their positions (Peta 2005).

Presenting her with the AfroAmerica Network black woman of the year, the AfroAmerica Network noted that Joice Mujuru was a member of the general staff of the Zimbabwe National Liberation Army (ZANLA) and in 1974 she was the commander of Chimoio Camp, Mozambique, at 19 years of age. Being the commander of a strategic camp such as Chimoio in an African liberation army during a 'bush war' would have been no mean accomplishment for a woman let alone at her young age. Her liberation struggle war name, nom de guerre, Teurai Ropa, assumed during the war of Zimbabwe's liberation literally means 'Spill blood', and implies ruthless dispatching of the enemy: the Rhodesian security forces, wherever she engaged them in the bush war. She therefore emerged from the war as one of the most senior Zimbabwean liberation fighters, renowned for her bravery and a specialist of firing rockets, mortars, and heavy weapons (Duri 2016: 15).

Subsequently, at independence in 1980, Mujuru became Mugabe's youngest cabinet minister at 25 years of age. She held various cabinet posts including being a Governor, rising to Vice President in 2004. When she was appointed Vice President, President Robert Mugabe reportedly said, "When you choose her as a vice president, you don't want her to remain in that chair do you?" (Mail and Guardian, 5 December 2004) - a suggestion that the public interpreted as meaning that Joice Mujuru was the running successor to President Mugabe when he chose to retire. In ZANU-PF, one does not ascend to such levels unless he/she has a well outlined war record that the party and its president acknowledges.

However, heroic praises for Joice Mujuru lasted as long as her party considered her and her faction a vital code and not a threat to Mugabe's autocratic rule. It is believed that by 2014, Mujuru commanded clear support from the majority of party structures to succeed Mugabe. Nine of the ten provincial chairpersons were purged on the basis of being Mujuru allies (Moyo 2016). In that regard it suffices to say that she was a challenger to Mugabe's continued presidency of the party 
and other rival presidential aspirants such as Emmerson Munangagwa. But, mention of succession to Mugabe is regarded as rebellion and 'selling-out'. It is seen as a potential threat to Mugabe hegemony, the supreme leader of the party. Therefore, Mugabe and her rival faction led by Emmerson Munangagwa portrayed her as a 'villain' and a person unworthy to be part of the revolutionary party. This is despite the fact that they had spent the previous three decades glorifying her war record.

Subsequently her illustrious liberation struggle record was turned upside down and publicly rejected. A number of her war records were challenged, implying that these were constructed rather than being real. As highlighted earlier, during these factional fights, individuals opposed to any hero being vilified emerged to give an alleged account of certain facts that had long been misrepresented. For example, then War Veterans Chairman Chris Mutsvangwa pointed out that Joice Mujuru never downed a helicopter during the liberation struggle but that this was mere party propaganda used to prop up her image (New Zim, 17 August 2014).

Further to this, a photo poster that had long been used depicting Joice Mujuru leading a group of ZANLA military forces in the war front line was now being contested. A woman war veteran, named Linda Mangwende (nom de guerre, Sarudzai Nehanda) was now quoted as saying that Joice Mujuru stole her photo (Gumbo 2015; Duri 2016: 18). Mangwende pointed out that the photo was taken in 1978 in Gaza Province, Mozambique. In order to leave no doubt in anyone's imagination, Mangwende is quoted as saying:

VP Mujuru has been using my picture claiming it is her after shooting down a helicopter, but the truth of the matter is that that is my picture that was taken in 1978 when I was coming from Takawira Sector entering Tangwena Sector in Gaza province ... I had left Comrade Kambanje (Tenzi Nehoreka) going to the sector where Comrade Aginyu Kambeu (the late General Amoth Chimombe), Freddy Matanga, Brigadier General Munemo, Grenjar Benhura, Tonderai Zimondi, Charles Munyoro and Tokwe were (Gumbo 2014).

Such assertions stripped Mujuru's fame as one of the leading heroines of the country's liberation struggle and poster girl of the liberation war.

Another strategy used to strip a war hero in these factional fights is to question or attack the persona of the concerned individual to reveal that the person is not worthy to be called a hero. Mujuru's persona was attacked by President Robert Mugabe who labelled her a 'rebel', 
adopting desperate measures to plot the downfall of the sitting President. Mugabe even argued that Joice Mujuru used two Nigerian witchdoctors in her alleged plot to have him killed (Daily Nation, 1 March 2015; Duri 2016: 19). In a further criticism of Mujuru's character, the wife of the President, Grace Mugabe, argued that she was "corrupt, an extortionist, incompetent, a gossiper, a liar and ungrateful", adding that she was "power-hungry, daft, foolish, divisive and a disgrace" (BBC News, 4 December 2014).

Another important weapon used to outwit rivals in the factional fights is the long used tag of 'sell-outs'. Grace Mugabe stated that Mujuru, the then Vice President, collaborated with white people to undermine the country's post-independence gains and had attempted to assassinate the President (Mail and Guardian, 17 November 2014). ZANU-PF and Mugabe himself view whites, America and the West as bitter enemies who should not be tolerated as they are seen as having brought misery to their government and the people of Zimbabwe, primarily through purported sanctions (The Daily News, 28 August 2013). Therefore, anyone who cooperates with them is not a hero.

Mujuru was also linked to the opposition and being among the architects of 'bhoramusango' (a strategy deployed to make ZANU-PF supporters vote for the opposition in the 2008 presidential elections), to upset President Mugabe and pave way for an inclusive government of ZANU-PF moderates and the opposition, the Movement for Democratic Change - MDC (Zindoga 2014). Opposition forces are also regularly referred to as 'sell-outs' and therefore anyone linked to them is viewed in the same light. Joice Mujuru was further accused of being instrumental in the formation of opposition outfit Mavambo/Kusile/Dawn of Simba Makoni with the assistance of her husband, former General Solomon Mujuru. The final nailing of Mujuru was done by Grace Mugabe when she declared that the former Vice President would not be buried at the national shrine if she died (NewsdzeZimbabwe, 15 October 2015).

Didymus Mutasa's fortunes also dipped because he was also linked to Mujuru. Mutasa is in the category of those initially recorded as among civilian heroes that played a critical role in the liberation struggle. The narrative applied to Mutasa prior to 2014 did not only serve to account for his purported heroic participation in the struggle but also to show the fact that the liberation struggle was not only fought through guerrilla warfare in the bushes of the then Rhodesia but that a variety of other strategies were employed. Such strategies some ascribed to Mutasa included mobilising recruits to join the liberation war, supporting 
comrades in detention or their spouses, mobilising international support and resources as well as sending future leaders outside the country for further studies (Phiri 2014).

Mutasa was initially recorded as having been politically active from a young age while a student at Goromonzi Secondary School where he had participated in student protests that challenged the white regime in Rhodesia (Phiri 2014). It was also argued that in the mid1960s, Mutasa, Guy Arthur Clutton Brock and their colleagues set up, the Cold Comfort Farm Society, and used it as a place to fight a protracted battle against Rhodesian settlers in general, and the lan Smith regime in particular (Mataire 2014a). Further to this, when outside prison, it was stated that Mutasa took care of detainees' wives, including regularly ferrying them to Gonakudzingwa Prison to visit their incarcerated husbands, and looking after their children at Cold Comfort.

Upon incarceration, Mutasa himself is said to have shared prison detention with other highly regarded heroes such as President Mugabe, Morris Nyagumbo, Enos Nkala, Mark Nziramasanga, and Morton Malianga as well as wedding his wife in prison (Phiri 2014). Following deportation to the United Kingdom (UK), he is alleged to have set up ZANUPF structures there. He is said to have run successful campaigns, including vigils that lobbied against the intended hanging of struggle stalwarts, Moven Mahachi, Morris Nyagumbo and John Mutasa (Phiri 2014). The Smith regime gave in to these demands. Further to this Mutasa was part of the high level delegates that attended the 1976 Geneva Conference before leaving the comfort of London to join the war in Mozambique. The Geneva Conference was meant to bring all parties to the Rhodesian (now Zimbabwe) conflict to a resolution though it was not successful.

In addition, Mutasa's wife, now a retired Brigadier General, Gertrude Mutasa, became a medical officer in the ZANLA army in 1977 where she was responsible for receiving, screening, treating and referring injured fighters from the war front, especially in the Mozambican Gaza province (The Herald, 7 October 2013). She only retired from the army in 2013.

With this war record, following independence, Mutasa became Zimbabwe's first Speaker of Parliament: 1980 to 1990. He later served as State Security Minister; and Minister of State for Presidential Affairs. These two appointments highlight that he was a close confidante of President Mugabe. Further, Mutasa's son, Wing Commander Edwin Tanyanyiwa Mutasa was Mugabe's personal helicopter pilot (Nehanda Radio, 17 November 2009). 
However, Mutasa lost the favour of President Mugabe when he chose to explicitly stand with Mujuru (Mukhongo and Macharia 2016). He was relieved of his politburo, Cabinet and Member of Parliament positions following the rise of the Mnangagwa faction at the 2014 Congress. As in the case of Mujuru, ZANU-PF and Mugabe enthusiasts also sought to undo any heroism previously attributed to Mutasa and portrayed him as a long time villain.

In the process of demonstrating that Mutasa is a villain, the period 1973-1980 when Mutasa was mainly in the UK, is now referred to as a period when he chickened out and or never bothered to partake in the liberation struggle and therefore has a vacuous war record to offer (New Zim, 17 August 2014). This argument emphasises the supremacy of participating in guerrilla military campaigns as a mark of heroism. It posits that Mutasa was averse to the taking up of arms and held a "utopian belief that the settler regime could be educated into regarding blacks as equals" (The Sunday Mail, 18 January 2015). Hence the title of his book Rhodesian Black Behind Bars is said to reveal that he was not a revolutionary who associated with the struggle as those in the struggle called themselves 'Zimbabweans'.

One of the ardent critics of Mutasa, war veteran Chris Mutsvangwa who was allied to the Munangagwa faction argued that Mutasa was misleading Mujuru to revolt and had a history of leading fellow party leaders astray (Nehanda Radio, 16 August 2014). He identified other leaders whom he alleged were previously misled by Mutasa as Edgar Tekere who went on to form his own party the Zimbabwe Unity Movement (ZUM) and later Simba Makoni who formed Mavambo/Kusile/ Dawn party.

The most startling disparagement came from the state media, ZANU-PF's propaganda machinery. The public press portrayed Mutasa as a sell-out who was an agent of the colonial British South Africa Police (BSAP) Special Branch (The Sunday Mail, 18 January 2015). It stated that Mutasa was described - in intelligence parlance - as a long-term 'sleeper', meaning he was deployed to destroy the liberation movement from within.

With respect to his persona, the state media also presented Mutasa as a fraud (Maodza 2015), who attempted to defraud Rusape Town Council of a house he was leasing; defaulted on rentals for a farm he was leasing in Makoni Rural District Council; refused to pay Zimbabwe Electricity Authority (ZESA) bills on his farm; and improperly distributed farms to his friends and relatives when he was Minister of Lands, Land Reform and Resettlement. This presented him as a dis- 
honest citizen rather than a gallant politician, thereby stripping him of his hero status that he had enjoyed since the 1980s.

Apart from Mutasa, Nicholas Goche is another long serving member of the Mugabe regime whose 'political dumping' highlights that war heroism in ZANU-PF mutates, is circumstantial and has been used in the party's factional fights. Goche once served as one of President Robert Mugabe's most trusted cabinet ministers having served in diplomatic postings and headed the feared Central Intelligence Organisation (CIO) as State Security Minister. He also served in other portfolios as Foreign Affairs Minister and Minister of Labour and Minister of Transport. Not much is written about Goche's liberation war credentials except that towards the tail end of the war, he crossed into Zambia to join the liberation struggle.

However, following the 2014 ZANU-PF Congress fall out based on factional lines; this part of his history has been modified. He is now alleged to have crossed into Zambia to run away from a criminal offence and is reported to have been saved from prosecution by a blanket law passed at independence to cover crimes committed during the war (New Zimbabwe, 22 November 2014). As part of denigrating him, Chris Mutsvangwa emphasises that:

there are chancers coming from nowhere like Goche. $(\mathrm{He})$ was part of the Rhodesian security apparatus until 1979 on the eve of the Lancaster House. He (Goche) is a defector from the Rhodesian intelligence apparatus, maybe an infiltrator. Because of his defection he ended up at an assembly point (Mataire 2014b).

In this regard Goche was now presented as a chancer and a villain. In addition, Goche, together with Mutasa and Rugare Gumbo were accused of orchestrating a plot to assassinate President Robert Mugabe so that Joice Mujuru would succeed as President and were reported to have held meetings with potential hitmen in South Africa and Israel (The Herald, 22 November 2015).

This allegation was made to dovetail into the argument that both Goche and Mutasa once had Rhodesian security spy links and therefore do not qualify to be among the generation of ZANU-PF struggle stalwarts. It does not spare Gumbo as well who is alleged to have preferred the company of the British instead of ZANU-PF at the onset of independence (Zindoga 2014). Making reference to South Africa (haven of Rhodesian whites), Israel and the UK is possibly also meant to show that the three were not representing the interests of the people of Zimbabwe and were therefore villains not heroes. 
Jabulani Sibanda, a long time war veterans leader known for his unparalleled defence of ZANU-PF is another hero turned villain due to the intra-party factionalism and the strategy of vilifying those perceived to be rebelling against Mugabe. During the liberation war, Jabulani Sibanda is said to have crossed into Zambia and then finally to Angola where he was trained and deployed, rising from an ordinary combatant to become an instructor, then a platoon commander, and finally a company commander (Kwaramba 2015a). Sibanda himself also claimed that he was the late Vice President Joshua Nkomo's bodyguard before and after Zimbabwe's independence in 1980. This automatically qualified him to be a war veteran of repute hence his election to the chairmanship of the Zimbabwe National Liberation War Veterans Association (ZNLWVA).

However, Jabulani Sibanda's case also highlights that even a combined war and post-war gallantry does not guarantee perpetual heroism in the context of ZANU-PF's factional fights. When Jabulani Sibanda was fingered in the infamous Tsholotsho Declaration of 18 November 2004, he was censured.

Under Sibanda's leadership the ZNLWVA mobilised War Veterans and other ZANU-PF sympathisers in the forced and often violent appropriation of whites' farmland which they claimed to have been stolen during colonisation. Sibanda was also linked to the 2008 crusade of violence perpetrated against opposition supporters, especially in Masvingo Province during the presidential run-off elections (Mushava 2013).

He was also one of the key organisers of the purported OneMillion-Man March in November 2007 to support the candidature of Mugabe in the 2008 presidential elections which drew thousands of ZANU-PF supporters on the streets of Harare. In return for this effort it is understood that Sibanda was awarded a brand new twin cab vehicle; a house in an up-market suburb of Harare, and his farm was heavily equipped (Moyo and Chambati 2013).

In 2011, Sibanda is reported to have gone around Masvingo, Manicaland, Mashonaland West and Matabeleland provinces, especially to constituencies that had lost the 2008 election to the opposition MDC, threatening people with violence and death and forcing villagers to attend his meetings that he dubbed 'Operation Kubudirana Pachena' (coming out into the open) (Mazarire 2013). Sibanda used the meetings to threaten opposition supporters to vote for ZANU-PF in the impending harmonised elections of 2013. If they did not support ZANUPF, Sibanda reminded them of the dire consequences of not doing so. 


\section{Sibanda warned:}

There shall come a day when you don't have time to put on your clothes and you will mistake your pants for a skirt. Repent now and get into the ark before it's too late, even if the ark is hot or smelly, it is worth enduring (Newsday, 19 July 2011).

During the more than a decade of violence, farm seizures and night rallies, Jabulani Sibanda remained untouchable, a hero and a darling of ZANU-PF and the President. However, once they believed that he belonged to a wrong faction led by Vice President Mujuru, he began to receive his own 'dose of vilifications' and his contribution to the struggle and loyalty to ZANU-PF over the years was cancelled.

Sibanda was seen as having crossed the line of disloyalty to Mugabe when he was arrested for saying he would oppose a 'bedroom coup', in remarks largely seen as opposing First Lady Grace Mugabe's rise to lead the ZANU-PF Women's League (NewsDay, 27 October 2014). Sibanda threatened to mobilise war veterans, youths and women to march to State House to confront the President. Sibanda had also boycotted the First Lady's 'Meet the people rallies' where the latter denigrated Vice President Joice Mujuru as a thief and not a war heroine.

With regards to Sibanda's character, a stunning accusation was made by the new Vice President, Mpoko, who alleged that he was once arrested in Angola for sodomising a fellow combatant during the country's liberation struggle (NewsdzeZimbabwe, 25 May 2015). As alledged in the case of Nicholas Goche, it was also pointed out that Sibanda escaped prosecution because of the change of government and proclamation of amnesty at independence. He was also described as a habitual liar and unworthy to be a hero in ZANU-PF (The Herald, 17 March 2016). Further to this, his age is now being disputed with some arguing that having been born in 1970, Sibanda could not have gone to war as he would have been nine years at independence. The 11 years he spent leading the ZNLWVA were described as an opportunity that Sibanda was granted to lead the revolutionary party but dismally failed (NewsdzeZimbabwe, 25 May 2015).

Another interesting figure who lost out on his hero status within ZANU-PF in 2014 was Rugare Gumbo. Gumbo's story brings to the fore, the fact that being a war hero is not a permanent status within ZANU-PF. The status can be stripped off or reinstated if the party and President Mugabe believe that one has been reformed and ready to toe the line, including in the circumstances of factional struggles.

Gumbo was readmitted into the party after being discarded at 
the end of the war in 1980. Amidst an opposition onslaught in the early 2000s, ZANU-PF went on a crusade to bring back some of the discarded struggle stalwarts possibly fearing that they would prop up the opposition MDC party. The party argued that its congress could rehabilitate some of the leaders who rebelled against the party even long before the war against lan Smith's white minority rule was over in 1980 (Msipa 2003). However, it is important to note that in the event that a rehabilitated individual falls foul of the party's expectation again, vilification can be resumed and the person can again be expelled. Rugare Gumbo is one leader who had such experiences.

The story of Rugare Gumbo is important because he is a veteran of the 1970s vicious liberation struggle. He served in the ZANUPF's supreme war council known as the Dare reChimurenga (War Council) that was responsible for executing the liberation struggle. It was headed by Robert Mugabe following the death of charismatic chairperson Herbert Chitepo in 1975. Gumbo was the Secretary of Information in the war council. A rise to that level in the struggle shows that he was a vital cog in the execution of the war.

Many times during the struggle, Mugabe confirmed the importance of Gumbo and other leaders in the liberation struggle. For example, when Chitepo was assassinated, Gumbo and other high ranking ZANU-PF officials were incarcerated by the government of Kenneth Kaunda. Mugabe came to their defence and castigated President Kaunda for the arrests and demanded the detainees release as a condition for ZANU-PF to participate at the October 1976 Geneva Conference (The Sunday Mail, 30 November 2014).

However, Gumbo was believed to have waged a rebellion in 1978 which resulted in his arrest on the instruction of Mugabe with Emmerson Mnangagwa as lead prosecutor (Kwaramba 2015b). Upon his release at the dawn of independence, ZANU-PF scrambled to have him and other members back in the fold, worrying that they would strengthen their political opponents but Gumbo refused (The Herald, 6 November 2014). Gumbo stayed in the political wilderness after fighting for a losing cause under Ndabaningi Sithole's ZANU-Ndonga in 1980.

However, ZANU-PF eventually succeeded in luring him back in early 2000 in response to the rising tide of opposition politics. He became a member of parliament and held the portfolios of Deputy Minister of Home Affairs; Minister of Economic Development and Minister of Agriculture. He was the ZANU-PF spokesman (Information and Publicity Secretary) at the time of his second demise.

Gumbo's political fortunes waned again in 2014 , when he was 
accused of choosing to work with a group of people (principally Joice Mujuru) seeking to undermine and unseat President Mugabe. (Zindoga 2014). His alleged liberation war rebellion, and participation in the independence elections under ZANU-Ndonga were revived. Even archives never heard before interviews were unearthed. Interviews on Gumbo that were said to have been done with the late Kumbirai Kangai (ZANUPF and Dare reChimurenga member) and the late Brigadier Hashim Mbita (Tanzanian Ambassador to Zimbabwe), both late, were carried in the state Herald. Both interviews did not portray Gumbo as a hero but a rebellious, troublemaker who always opposed other comrades in the struggle (Zindoga 2014). He was also portrayed as having favoured working with the British and puppets of the Rhodesian regime at the onset of Zimbabwe's independence.

In trying to completely bury Gumbo, assassination claims were made against him and the state-owned Herald wrote:

Zanu-PF secretary for administration Cde Didymus Mutasa and deposed spokesperson Rugare Gumbo - who were recorded saying if President Mugabe blocked Vice President Joice Mujuru's ascendancy he would be shot and deposed the Kabila way - indicate that something ominous was in the offing in Zanu-PF ahead of the congress (The Herald, 22 November 2014).

Hence he no longer deserved any hero status. The vilification of these ZANU-PF leaders in the party's factional struggles and their subsequent expulsion gave an upper hand to one faction led by Emmerson Mnangagwa, now Vice President.

However, suffice to say that those who denigrate other ZANU-PF leaders as villains are in the right position but it would be misrepresentation to say that they are themselves war heroes. The praise and vilification processes are continuing as a result of intensifying factionalism buoyed by the aging Mugabe. Recently, the team that vilified the above five ZANU-PF leaders also seem to have split into two groups, one led by Emmerson Mnangagwa and another headed by First Lady Grace Mugabe.

Subsequently, despite having almost stood shoulders high above the rest, arguing that Mujuru and others were not heroes as the party's factional war escalated, Christopher Mustvangwa, who took over leadership of the War Veterans Association from Jabulani Sibanda and became the responsible minister, has had the tables turned against him. He has since been dismissed allegedly for insulting the First Lady, Grace Mugabe (Daily News, 15 December 2015). Indeed some analysts 
have argued that:

The move to remove Mutsvangwa is seen as part of the wider succession battle to succeed the ailing Mugabe. The outspoken Mutsvangwa is a key ally of Vice President Emmerson Mnangagwa's (Team Lacoste faction), while the Generation 40 (G40) faction angling to remove him, are trying to propel first lady Grace Mugabe to be president instead (Nehanda Radio 2015).

In that regard, Vice President Mnangagwa has not been spared of vilification and signs of his dismissal are also on the horizon. Recently, Grace Mugabe is alleged to have insinuated that those behind Mnangagwa were responsible for the recent bombing of her dairy farm and wanted to kill her youngest son Bellarmine Chatunga and that Mnangagwa was a womaniser (Daily News, 13 February 2016). She also argued that there were individuals who behaved as though they were 'super war heroes', with reference to Christopher Mustvangwa. While Mutsvangwa is gone, serious warning shots have been made to Vice President Mnangagwa; making the cycle of creating heroes and vilifications in ZANU-PF an ongoing process as factional fights intensify.

\section{Conclusion}

The article has revealed that recognition of war hero status in ZANUPF's factional struggles is built around the perspective of the party and its President. It is a partisan process that depends on whether the party and President still want to work or recognise certain individuals and their factions. Using the case of liberation war leaders, Joice Mujuru, Didymus Mutasa, Rugare Gumbo, Jabulani Sibanda and Nicholas Goche we explained how their hero status has been made or withdrawn on account of factional struggles. Therefore, the hero status is one which is temporal, often artificial as ZANU-PF and President Mugabe have the political power to strip it or bestow it. Hence, hero status is not only about an individual's contribution to the liberation struggle, but their circumstances vis-à-vis the dominant party faction at any given time.

\section{Bibliography}

Alexander, J (1998), "Dissident Perspectives on Zimbabwe's Post-independence War, Africa", Journal of the International Africa Institute, Vol 68, No 2, pp 151182. 
Alexander, J and J McGregor (2004), "War stories: Guerrilla narratives of Zimbabwe's liberation", History Workshop Journal, Issue 57, Spring, pp 79-100.

Baines, G (2009), "Site of struggle: The Freedom Park fracas and the divisive Legacy of South Africa's Border War/Liberation Struggle", Social Dynamics, Vol 35, No 2, pp 330-344.

BBC News (2014), "Grace Mugabe profile: The rise of Zimbabwe's first lady", 4 December.

Belloni, F P and D C Beller (eds) (1978), Faction Politics: Political Parties and Factionalism in Comparative Perspective. Santa Barbara, California: ABC-Clio Press Ltd.

Bettcher, K E (2005), "Factions of Interest in Japan and Italy: The Organizational and Motivational Dimensions of Factionalism", Party Politics, Vol 11, No 3, pp 339-358.

Boucek, F (2009), "Rethinking Factionalism - Typologies, Intraparty Dynamics and Three Faces of Factionalism", Party Politics, Vol 15, No 4, pp 1-31.

Chikuhwa, J (2004), A Crisis of Governance in Zimbabwe. New York: Algora.

Chung, F (2006), Re-living the Second Chimurenga: Memories from the liberation struggle in Zimbabwe. Stockholm: The Nordic African Institute and Weaver Press.

Cox, G W, Rosenbluth, F M and M F Thies (2000), "Electoral Rules, Career Ambitions, and Party Structure: Comparing Factions in Japan's Upper and Lower Houses", American Journal of Political Science, Vol 44, No 1, pp 115- 122.

Dandeker, C, Wessely, S, Iversen, A and J Ross (2006), "What's in a Name? Defining and caring for 'veterans': The United Kingdom in international perspective", Armed Forces and Society, Vol 32, No 2, pp 161-177.

Duri, F P T (2016), "Presentism, Contested Narratives and Dissonances in Zimbabwe's Liberation War Heritage: The Case of Joice Mujuru", in Mawere, M and T R Mubaya (eds), Colonial Heritage, Memory and Sustainability in Africa: Challenges, Opportunities and Prospects. Cameroon: Langaa Research and Publishing Initiative Group.

Goredema, D and P Chigora (2009), "Fake heroines and the falsification of history in Zimbabwe 1980-2009", African Journal of History and Culture, Vol 1, No 5, pp 76-83.

Gumbo, L (2014), "VP Mujuru Stole my Picture: War Veteran", The Herald, 2 December.

Kwaramba, F (2015a), "Mugabe never trusted ex-Zipra guerillas — Sibanda", Daily News, 1 June.

Kwaramba, F (2015b), "Zanu PF bigwigs wanted to kill me", Daily News, 9 May.

Makinwa, B (2015), "A Nation Hostage to the Typist's Script". (Available at: http:// www.newzimbabwe.com/news/printVersion.aspx?newsID=19814, last accessed 4 February 2016.)

Maodza, T (2015), "Mutasa: Behind the bitterness", The Herald, 26 June. 
Mataire, L (2014a), "Relieving the Cold Comfort Farm Society", The Herald, 14 April. Mataire, L (2014b), "We are Alert, Vigilant in Crisis Moments", The Herald, 22 November.

Mazarire, G (2013), "ZANU-PF and the Government of National Unity", in Raftopoulos, B (ed), The Hard Road to Reform: The Politics of Zimbabwe's Global Political Agreement. Harare: Weaver Press.

Mhanda, W (2011), Dzino: Memories of a freedom fighter. Harare: Weaver Press.

Moyo, H (2016), "Zanu PF plots to shipwreck Mujuru Project", The Zimbabwe Independent, 11 March.

Moyo, S and W Chambati (2013), Land and Agrarian Reform in Zimbabwe.Beyond White-Settler Capitalism. Dakar: CODESRIA.

Msipa, A C (2003), "Mugabe Swallows his Pride", Mail and Guardian, 4 November.

Mukhongo, L L and J W Macharia (2016), "Media, Democracy and Political Change in Developing Countries", in Mkuhongo L L and J W Macharia (eds), Political Influence of the Media in Developing Countries. Pennsylvania: IGI Global.

Mushava, E (2013), "Jabulani Sibanda at it again", Newsday, 13 February.

Ndlovu-Gatsheni, S J (2007), "Fatherhood and Nationhood: Joshua Nkomo and the Re-imagination of the Zimbabwe Nation", in Muchemwa, K and R Muponde, Manning the Nation: Father figures in Zimbabwean literature and society. Weaver Press: Harare, pp 73-87.

Ndlovu-Gatsheni, S J (2009), Do Zimbabweans' Exist: Trajectories of Nationalism, National Identity Formation and Crisis in a Postcolonial State. Bern: Peter Lang.

Ndlovu-Gatsheni, S J (2013), "The crisis of adapting history in Zimbabwe", in Raw, L and De E Tutan (eds), The adaptation of History: Essays on ways of telling the past. North Carolina: McFarland \& Co, pp 129-140.

Nehanda Radio (2015), "Mutsvangwa booted out", 14 December.

Newsday (2011), "Jabulani Sibanda humilitated (sic)", 19 July.

Peta, B (2005), "Zimbabwe's Most Powerful Woman or Pawn", News Africa, 9 January. (Available at: http://www.iol.co.za/news/africa/zimbabwe-s-mostpowerful-woman-or-a-pawn-1.231148?ot=inmsa.ArticlePrintPageLayout.ot, last accessed 12 December 2015).

Phiri, G (2014), "Mutasa Backers Hit Back at Mutsvangwa", Nehanda Radio, 4 September. (Available at: http://nehandaradio.com/2014/09/04/mutasabackers-hit-back-at-mutsvangwa/\#sthash.20176xdO.dpuf, last accessed 28 December 2015.)

The Herald (2014), "Goche discussed assassination plot", 22 November.

The Sunday Mail (2015), "Revealed: Didymus Mutasa's Rhodesian spy links", 18 January.

Werbner, R (1998), Memory and the postcolony: African anthropology and the critique of power. London: Zed Books.

Zariski, R (1960), "Party Factions and Comparative Politics: Some Preliminary Ob- 
servations", Midwest Journal of Political Science, Vol 4, pp 27-51.

Zindoga, T (2014), "Rugare Gumbo: Fly that can never deliver honey". The Herald, 10 November.

Zuckerman, A (1975), Political Clienteles in Power: Party Factions and Cabinet Coalitions in Italy. London: Sage Publications. 